\title{
The Effectiveness of Information Services with the Jigsaw Cooperative Learning Model to Improve the Understanding of Discipline Learning of the Student
}

\author{
Arip Martua Hasibuan'1, Riska Ahmad ${ }^{1}$, Yarmis syukur ${ }^{1}$ \\ ${ }^{1}$ Universitas Negeri Padang \\ ${ }^{*}$ Corresponding author, e-mail: arip.hasibuan28@gmail.com
}

\begin{abstract}
The less understanding of the discipline learning by the student causes students to violate the rules and regulations that have been set in the school environment. This problem occurs because students are not aware of the meaning of the discipline learning, so it takes effort to improve students' understanding of the discipline learning. The understanding of learning discipline of the student is not seen in terms of attendance at school, taking lessons in class, managing time, school rules and free time. One of the efforts that made in improving student understanding is by the information service of the Jigsaw Cooperative Learning model. This study aimed to test the effectiveness of information services with the Jigsaw Cooperative Learning model to improve students' understanding of the discipline learning. This research used quantitative methods. The type of research was a Quasi Experiment with the design of The One Group Pretest-Posttest (without using a control group). The population of this study were Dian Andalas Padang High School students and the sample was selected using the Purposive Sampling technique. The instrument of the research was using a Likert Scale model (a questionnaire about the understanding of student learning discipline), the data were analyzed with the Wilcoxon Signed Ranks Test with the help of SPSS version 20. The results showed that the average score of pretest 123 and posttest 160 . Based on the results of this study, it was concluded that the service information with the Jigsaw Cooperative Learning model is effective for increasing understanding of student learning discipline.
\end{abstract}

Keywords: Student Understanding, Information Services, Jigsaw Cooperative Learning Model, Learning Discipline

\section{Introduction}

Education is a major factor in the formation of the human person. Education is very instrumental in shaping the good or bad of the human person according to normative measures. Prayitno (2013) explains that educational goals are basically the direction to be achieved in order to realize the goals of human life, namely living according to Human 
Rights and Dignity (HMM), with all its contents, dimensions of humanity and understanding In the process of education an interaction occurs between teachers and students who essentially no different. Both occur in a dynamic process "to be". This means that education aims to make a complete and perfect human being. On this basis, it can be concluded that the teacher is an agent of learning that prepares students to develop their potential optimally.

Tu'u (2012) states that discipline is very important and needed by every student, because discipline is a prerequisite for the formation of attitudes, behaviors and life arrangements, a discipline that will lead a student to success in learning and later when working. Discipline attitude that is brought from the family environment is a big capital for the formation of a disciplined attitude in the school environment. Habitual habits at school will have a positive influence on student life in the future. Mayer (1989) argues that understanding the discipline of student learning involves a lot of cognitive work.

Discipline is an action that shows orderly and compliant behavior in various rules and regulations. Besides discipline is a person's ability to show the best in all situations through controlling emotions, words, encouragement, desires, and actions. Discipline is not only someone's adherence to the rules that apply but also relates to a person's attitude, behavior, and words. It can also be said that discipline is the rules or regulations (at school, army, etc.) which are set to train someone to behave well and obey or obey the rules, rules that have been set. Discipline is not only orderly or disciplined in implementing rules but also training someone to behave well, obey, and comply with the rules. Then the indicators of discipline are a) orderly, b) obedient, and c) good behavior (Hartin, 2019).

Based on the characteristics of the above learning disciplines, students who are disciplined of course carry out learning activities regularly, complete assignments on time, diligently read textbooks, pay attention to lessons delivered by the teacher, diligently ask questions or express opinions, avoiding self from actions that hinder the smooth learning , make important notes and obey school rules. Prijodarminto (2014) explained that the discipline was seen through the assistance of educators, both parents, teachers, and the community. Discipline is the first step towards achieving educational goals. Discipline involves individual students, that is, the attainment of a social value and attitude that makes it possible to make self-correction and be responsible. Therefore, students should be able to behave and behave in accordance with existing provisions, so that the activities carried out can run smoothly so that good results are obtained (Irianto \& Fadrian, 2014). Therefore, Syafrudin (2005) divides learning discipline indicators into four types, namely: 1) observance of study time, 2) observance of lesson assignments, 3) adherence to the use of learning facilities, and 4) observance of using time to come and go home .

Purwanto (2007) explains that the factors that influence the discipline of learning include, internal and external factors. Internal factors such as, maturity, growth, intelligence, exercise, student motivation, and health conditions of students. External factors include, teaching materials, learning aids, and learning atmosphere. These factors indicate that the discipline of learning is not only influenced from within students themselves but also influenced by outside students. Imron (2012) explains that people who succeed in their respective fields generally have high discipline, whereas people who fail are generally undisciplined. Students who are diligent and disciplined in learning will succeed in doing their schoolwork, because the demands of each task are high study habits and routines (Willis, 2012). 
Based on preliminary observations made on October 22, 2018 at Dian Andalas High School, it is known that students already know the rules and regulations in school, but problems are still found regarding the lack of understanding of the learning discipline that is often faced by Dian Andalas High School students including as The following, 1. Often late students enter school, it can be seen from the behavior of students who come almost every day late, so that it can be seen from the picket book that almost every day contains students who arrive late for various reasons, 2. Less polite and lack of respect for the teacher. This phenomenon can be seen from the presence of students who often go in and out of class and often sit in the school canteen during learning hours, 3. Found students who do homework at school, 4 . There are students who play truant during learning hours. This can be seen from the recapitulation of absences on a weekly basis, and 5. Lack of enthusiasm in following the lessons. This can be seen from the attitude of students in following the lessons. Therefore, this study aims to examine the effectiveness of information services using the Jigsaw Cooperative Learning model in an effort to improve students' understanding of learning discipline.

\section{Method}

This type of research is quantitative research with experimental research design, using the design of the initial test (pretest) and the last treatment (posttest). The experimental design used in this study was the experimental design of the Quasi Experiment model, with The One Group Pretest-Posttest research design. This design consists of one group (no control group). The study was conducted at Dian Andalas Padang High School, the school the researcher chose based on several considerations, namely: the availability of research subjects in accordance with what he wanted to study, this school has an A accreditation also has a BK teacher in accordance with the provisions, making it easier for researchers to conduct intensive activities. The subjects in this study were the XI grade students of Dian Andalas Padang High School. The instrument used was a Likert scale model based on a questionnaire understanding student learning discipline, while the research variables used validity and reliability. While the data analysis technique uses nonparametric statistics with the Wilcoxon Singed Rank Test, with the aim of seeing differences in the conditions of understanding student learning discipline, before and after treatment is given.

\section{Results and Discussion}

The data in this study were included (1) the condition of students 'understanding of the learning discipline of the experimental group before being treated with the Jigsaw Cooperative Learning model, (2) the condition of students' understanding of the experimental group's learning discipline after being treated with the Cooperative Learning model of the Jigsaw type , (3) the differences in the conditions of understanding the students 'discipline of the pretest and Posttest experimental group students with the conditions of understanding the students' discipline of the experimental group.

\section{Conditions of Understanding Student Learning Discipline in Experimental Group Pre- Treatment (Pretest)}

Pretest data description of students' learning discipline understanding can be seen in Table 1. 
Table 1. Frequency Distribution of Pretest Results

\begin{tabular}{lccc}
\hline \multicolumn{1}{c}{ Category } & Score Interval & f & \% \\
\hline Very high & $\geq 190$ & 0 & 0 \\
High & $154-189$ & 0 & 0 \\
Is & $118-153$ & 12 & 60 \\
Low & $81-117$ & 8 & 40 \\
Very low & $\leq 80$ & 0 & 0 \\
\hline
\end{tabular}

Table 1 shows that the majority of students $60 \%$ have moderated learning discipline understanding, and the other $40 \%$ students have low learning discipline understanding. Therefore the understanding of student learning discipline seen from the results of the average score is 123 . which is equal to $40 \%$, the average score of student learning discipline understanding is 123 . The understanding of student learning discipline is in the medium category.

\section{Conditions of Understanding Student Learning Discipline in Experimental Group Pre- Treatment (Posttest)}

Posttest data description about understanding student learning discipline can be seen in the following.

Table 2. Frequency Distribution of Posttest Results

\begin{tabular}{lccc}
\hline \multicolumn{1}{c}{ Category } & Score Interval & f & \% \\
\hline Very high & $\geq 190$ & 0 & 0 \\
High & $154-189$ & 19 & 95 \\
Is & $118-153$ & 1 & 5 \\
Low & $81-117$ & 0 & 0 \\
Very low & $\leq 80$ & 0 & 0 \\
\hline
\end{tabular}

Table 2 above shows that 19 students experienced an increase in understanding of the discipline of learning and were in the high category that was 95\%, and only 1 student still had a moderate understanding of learning discipline which was $5 \%$. The average score of student learning discipline understanding is 160 , so it can be concluded that the understanding of student learning discipline is in the high category.

\section{Differences in Pretest and Posttest Results Conditions for Student Learning Discipline}

The description of the pretest-posttest data about the understanding of student learning discipline can be seen in Figure 1. 


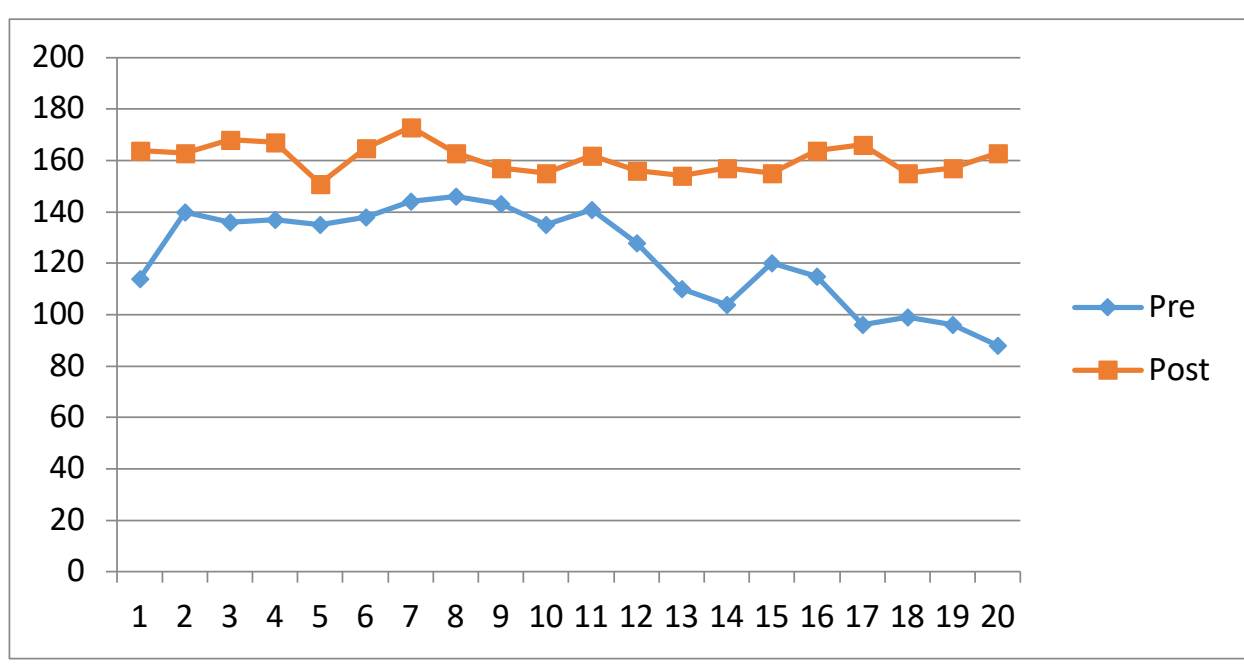

Figure 1. Pretest and Posttest Results of Student Learning Discipline Understanding

Based on the picture above, it can be concluded that the understanding of student learning discipline has increased about the understanding of learning discipline after being treated with Jigsaw Cooperative Learning model information services, this can be seen based on the results of the pretest and posttest.

\section{Discussion}

Understanding Student Learning Discipline in Experiment Group Before Being Given Pretest

The description of students' learning discipline understanding was obtained through the pretest results which are 123 in the medium category, based on this it can be interpreted that the information services carried out by only using the lecture method so that some students have a particular concern about understanding the discipline of learning, so students experience disturbing conditions when are in the process of learning in class. This can also be seen from the inactivity of students in participating in learning, such as most of the students who enter and exit the class during class time, but there are some other students who continue to follow learning well and regularly.

Pretest results indicate the condition of understanding student learning discipline was in the medium category, students' understanding of the discipline being able to affect learning achievement and can result in a lack of student concentration in learning. Because discipline is a behavior that needs to be implemented and carried out by every individual to achieve success in the future. Discipline if it is developed and implemented well, consistently and consequently will have a positive impact on life. According to Tu'u (2012) discipline is very important and needed by every student, because discipline is a prerequisite for the formation of disciplined understanding, attitude, behavior and life order, which will lead a student to success in learning and later when working.

Problems with student learning discipline are usually apparent from declining academic performance or learning outcomes. These problems are influenced by several factors, generally derived from internal factors, namely from the students themselves and external factors that come from outside. Some factors that affect discipline are as follows. 
1. Self-awareness, serves as self-understanding that discipline is considered important for his good and success. Besides self-awareness becomes a very strong motive for the formation of discipline.

2. Followers and obedience, as a step in applying and practicing the rules that govern individual behavior. This is a continuation of the existence of self-awareness generated by the ability and strong self-will.

3. Educational tools, to influence, change, foster and shape behavior in accordance with the values determined and taught.

4. Punishment, as an effort to sensitize, correct and correct the wrong so that people return to behavior in accordance with expectations (Tu'u, 2012).

This is in line with the results of Hartin's research (2019) which states that discipline is an act that shows orderly and obedient behavior in various rules and regulations. Besides discipline is a person's ability to show the best in all situations through controlling emotions, words, encouragement, desires, and actions. Discipline is not only someone's adherence to the rules that apply but also relates to a person's attitude, behavior, and words.

Based on the opinion above, it can be concluded that the discipline of learning is the regularity of students in undergoing the learning process in accordance with the rules and following it well. Discipline is not only applied to students but also applies to all members of the organization in the school. Discipline that is owned by a student will help students themselves in daily behavior, both at school and at home. Students will easily adjust to the environment they face. The rules obtained at school can be implemented well if students already have the existing discipline in themselves.

Understanding Student Learning Discipline in Experiment Group After Treatment (Posttest)

The understanding of students' learning discipline was obtained through the posttest results with an average score of 160 included in the high category. Based on these results it can be interpreted that the understanding of the discipline of learning felt by students after participating in information service activities with the Jigsaw Cooperative Learning model experienced changes and an increase in the average score of students' learning discipline understanding before participating in the treatment. The students' understanding of the learning discipline referred to in this study is forming a life attitude, deeds and habits in following the learning process in accordance with applicable regulations and undergoing learning activities both at school and outside of school. As Prayitno (2012) explained that the information service aims at the mastery of certain information by participants of information services that are useful for their daily needs (in the context of effective daily living) and their development.

The posttest results showed that the condition of understanding student learning discipline after participating in information service activities with the Jigsaw Cooperative Learning model was in the high category. An increase in students' understanding of the discipline of learning can be seen in terms of the material discussed in information services and can be seen in terms of the models used in the implementation of information services. In terms of the material provided in the information service related to the understanding of student learning discipline is about using study time, doing assignments on time, filling free time, using learning facilities, and following learning in class. 
The implementation of learning activities is influenced by various factors, one of which is motivation. According to Sarlito W. Sarwono (2012) student motivation is influenced by subject matter and teachers, limited teachers and infrastructure, situations and conditions of the educational environment, social environment and lack of support from parents. One way that can be done to improve understanding is to carry out information services (Oki, Syukur, \& Sukma, 2013).

Based on the implementation of information service activities with the Jigsaw Cooperative Learning model, it was revealed that there was a change in the understanding of the discipline of learning owned by students. success. All individuals believe that every student would want to achieve success (Wibowo, 2013). Based on this understanding individuals have the idea that success and success is something that must exist in every person, so that if they do not get success and success from the people they value, it will lead to behaviors that hinder individual happiness.

Young (Glading, 2012) explains that understanding generally changes through the process of re-conceptualizing, a technique that offers students other possibilities and positive perspectives or perspectives about a situation. Changes in perspective like this give students a different way to respond. Furthermore Sudjana (2011) explains the process of teaching and learning that is good, should use various types of teaching methods alternately or hand in hand with each other. Each method has its weaknesses and advantages, so it is the teacher's job to choose the right methods to create a learning process. The exact use of the teaching method is very dependent on the objectives, the contents of the teaching and learning process and teaching and learning activities.

Based on the explanation above, it can be understood that it is necessary to have an effort to carry out information services with a Jigsaw Cooperative Learning model specifically material about understanding student learning discipline, so that students not only get general knowledge and insight but students can also directly understand the treatment that is applied. What was seen during the observation process that was carried out when students joined information services was that students were enthusiastic and enthusiastic about participating in group discussion activities with the Jigsaw model, began to dare to express opinions, students were able to appreciate others who were talking, and students began to have an interest in knowing information about understanding student learning discipline and its benefits for daily life.

Effectiveness of Information Services with a Jigsaw Cooperative Learning Model to Improve Students' Discipline Understanding

The implementation of information service activities using the Jigsaw Cooperative Learnig model to enhance the understanding of student learning discipline is carried out through seven treatments. The implementation of information services has three stages, so that implementation is in accordance with the objectives of the study, for that information services are carried out in a classical format. Information service is a service to equip students with knowledge about data and facts in the field of school education, work fields, and the field of social personal development, so that those who learn about their environment are better able to organize and plan their own lives (Winkel \& Hastuti, 2006) . Prayitno (2012) argues that information services are services that try to meet the individual's lack of the information they need. 
The success of students in learning not only must be obtained from the teacher, but can also from other parties involved in the learning, namely peers. In line with what was expressed by Anita Lie (2002) that teaching by peers (peer teaching) turned out to be more effective than teaching by teachers.

Cooperative Learning learning method is one of the learning methods that support constructivistic learning (Suparno, 2007). Cooperative Learning teaching system can be defined as a work system / structured group learning. Five main elements that must be applied in Cooperative Learning methods, namely positive interdependence, individual responsibility, personal interaction, expertise in working together, and group processes (Lie, 2002). In completing their group assignments, each student group member must work together and help each other to understand the subject matter. In cooperative learning, learning is said to be incomplete if one of the friends in the group has not mastered the lesson material (Musthofa, 2013).

According to Riska Ahmad (2017) there are several goals that must be achieved in Cooperative Learning, including the following.

1. Improve the ability of social relationships, foster an attitude of accepting lack of self and others, and can increase self-esteem.

2. Develop the ability to accept other people with different backgrounds, so as to enable cooperation, interdependence in doing the task, through the structure of cooperative rewards will occur to one another.

3. Helping students to realize their needs to learn to think, solve problems, integrate knowledge and skills

In the research of Arends Ricards (2008) Jigsaw Cooperative Learning, a cooperative learning model consisting of several members in a group responsible for mastering the learning material section and being able to work on that part to other members in the group. Kessler (1992) describes Jigsaw's activities by grouping and division of tasks, among others.

Work in expert groups

Students create new groups, in expert groups, students discuss material in expert groups and practice presentations in jigsaw groups. The teacher guides each group, discusses and receives responses to questions, helps students prepare for each other in a jigsaw group.

Work in jigsaw groups

When all groups felt they were ready in terms of understanding all the material discussed and were ready to share information, students returned to the jigsaw group. Each student presents the results of the expert group discussion to the jigsaw group, in this case students are encouraged to utilize all the knowledge they have. After students share information and discussion in a jigsaw group, each group has the opportunity to review the material before the teacher holds a quiz or gives questions. The quiz or question is for all students and is based on the contents and vocabulary of all reading and discussion jigsaw groups.

Based on the above analysis, it can be concluded that information services using the Jigsaw Cooperative Leaarning model are more effective in increasing students' understanding of the discipline of learning. This effectiveness is involved in the total number 
of analyzes conducted in which the scores of students' understanding of the discipline of the experimental group have increased. Thus, the use of varied and innovative teaching methods in information services makes their implementation easy, creative and fun. Based on the results of the data analysis above, it can be concluded that information services with the Jigsaw Cooperative Leaarning model can improve students' understanding of the discipline of learning.

\section{Conclusion}

Based on the research results obtained and analyzed with statistics and tested the hypothesis, it can be concluded in general that information services with the Jigsaw Cooperative Learning model are effective for increasing students' understanding of the discipline of learning, while in particular are: conditions of understanding student learning discipline before being given treatment ( pretest) is in the medium category which means that the condition of understanding student learning discipline that is perceived to be disruptive in the learning process, the condition of understanding student learning discipline after being given treatment (posttest) is in the high category which means that the condition of understanding student learning discipline that is felt is not too disturbing in the learning process, there are differences obtained significantly based on the average score of students' discipline in the experimental group before being treated (pretest) and after being given treatment (posttest) through service and information using the Jigsaw Cooperative Learning model, where the posttest average score increased from the pretest average score.

\section{References}

Ahmad, R. (2017). Buku ajaran bimbingan klasikal. Padang: Sukabina Perss.

Arends R. (2008). Learning to each mc. Graw : Hill International Edisi tujuh Pustaka Pelajar.

Fadrian, A., \& Irianto, A. (2014). Pengaruh kemandirian belajar, disiplin belajar dan motivasi berprestasi terhadap perilaku menyontek mahasiswa fakultas ekonomi universitas negeri padang.

Glading, Samuel T. (2012). Konseling: profesi yang menyeluruh. Jakarta: Indeks.

Hartin. (2019). Pembelajaran kooperatif tipe stad dalam peningkatan minat belajar dan disiplin siswa di sdn 18 baruga, 25, 108-134.

Imron, A. (2012). Manejemen peserta didik berbasis sekolah. Jakarta: Bumi Aksara.

Kessler, C . (1992) Cooperative language learning . New Jersey : Prentice Hall Regents.

Lie, A. (2002), Cooperative learning (mempraktikkan cooperative learning di ruang- ruang kelas), Jakarta: Gramedia Widiasarana.

Musthofa, K. (2013). Pembelajaran fisika dengan cooperative learning tipe jigsaw untuk mengoptimalkan aktivitas dan kemampuan kognitif siswa kelas x-6 SMA MTA surakarta. Jurnal pendidikan fisika, vol.1(1).

Mayer, R.E. (1989). Systematic thinking fostered by systematic illustrations in scientific text. Journal of Educational Psychology, Vol 8 (1). 
Oki, S. S., Syukur, Y., \& Sukma, D. (2013). Peningkatan motivasi belajar anak asuh melalui layanan bimbingan kelompok di panti asuhan al-falah padang. Konselor, 2(4).

Prayitno. (2012). Jenis layanan dan kegiatan pendukung. Padang: FIP UNP.

Purwanto, N. (2007). Psikologi pendidikan. Bandung: Remaja Rosdakarya.

Syafruddin. (2005). Hubungan antara disiplin belajar dan perhatian orangtua dengan hasil belajar bahasa Indonesia SMA PGRI Sungguminas Kabupaten Gowa. Jurnal Edukasi. No. 2. 79-85. FIP. Universitas Negeri Makasar.

Sarlito W, Sarwono. (2012). Psikologi remaja. Jakarta: Rajawali Pers.

Suparno, P. (2007). Metodologi pembelajaran fisika: kontrutivistik dan menyenangkan. Yogyakarta: Universitas Sanata Dharma.

Sudjana, N. (2011). Dasar-dasar proses belajar mengajar. Bandung: Sinar Baru Algensindo.

Tu'u, T. (2012). Peran disiplin pada perilaku dan prestasi siswa. Jakarta: Gramedia Widiasarana.

Willis, S.S. (2012). Psikologi pendidikan. Bandung: Alfabeta.

Wibowo, Agus. (2013). Manejemen Pendidikan Karakter di Sekolah. Yogyakarta: Pustaka Pelajar.

Winkel \& Hastuti, S. (2013). Bimbingan dan konseling di institusi pendidikan. Yogyakarta: Media Abad. 